\title{
15 Temmuz Darbe Girişiminin Milliyetçi Söyleme Etkisi: Cumhurbaşkanı Erdoğan’ın Yenikapı Mitinginde Yaptığı Konuşmanın Analizi
}

\section{The Impact of the 15 July Military Coup Attempt on Nationalist Discourse: Analysis of President Erdoğan's Speech at Yenikapı Demonstration}

\author{
Dr. Öğr. Üyesi Yusuf Ziya Bölükbaşı ${ }^{1}$
}

Başvuru Tarihi: 19.11.2019

Kabul Tarihi: 03.12.2019

\section{Öz}

Bu çalışmada, Cumhurbaşkanı Recep Tayyip Erdoğan'ın 15 Temmuz Darbe ve İsgal Girişiminden sonra Yenikapı Mitinginde yaptığı konuşmanın analizi, milliyetçilik çerçevesinde yapılması amaçlanmaktadır. Bu yüzden mevcut çalışmanın kavramsal çerçevesini milliyetçilik, Türk milliyetçiliği ve 15 Temmuz Darbe ve İşgal Girişimi oluşturmaktadır. Milliyetçiliğin bir söylem biçimi olması üzerinde durulmaktadır. Türk milliyetçiliği ise, geç bir dönemde ortaya çıkışı, reaksiyoner karakteri ve devlete dayalı bir ideoloji olma nitelikleri temelinde incelenmektedir. Bu çalışmanın metodolojik çerçevesini Eleştirel Söylem Analizi oluşturmakta, bu yaklaşın içinde mütalaa edilen Dijk'in Politik Söylem Analizi kullanılmaktadır. Cumhurbaşkanı Erdoğan'in söyleminde ön plana çıkan devlet, vatan, bağımsızlık, toplumsal bütünlük, ezan, şehitlik, emperyal güçlere ve terörizme karşı mücadele olguları milliyetçi söyleme işaret etmektedir. Bu söylemler, Türk milliyetçiliğinin reaksiyoner yapısı ve devleti koruma içgüdüsüyle birlikte 15 Temmuz Darbe Girişiminin etkisiyle biçimlendiği görülmektedir.

Anahtar Kelimeler: Milliyetçilik, 15 Temmuz Darbe Girişimi, Cumhurbaşkanı Erdoğan, Söylem Analizi, Devlet

\begin{abstract}
In this study, it is aimed to analyze the speech made by President Recep Tayyip Erdoğan at the Yenikapi Demonstration after the July 15 Coup and Occupation Attempt and to be conducted within the framework of nationalism. Therefore, the conceptual framework of the present study is nationalism, Turkish nationalism and the July 15 Coup and Occupation Attempt. It is emphasized that nationalism is a form of discourse. On the other hand, Turkish nationalism is examined on the basis of its emergence in a late period, its reactionary character and the characteristics of being a state-based ideology. Critical Discourse Analysis is the methodological framework of this study and Dijk's Political Discourse Analysis is used in this approach. The state,
\end{abstract}

\footnotetext{
${ }^{1}$ Bilecik Şeyh Edebali Üniversitesi Uluslararası İlişkiler Bölümü, yusuf.bolukbasi@bilecik.edu.tr, ORCID ID: 0000-0003-4723-5977
} 
homeland, independence, social cohesion, the azan, martyrdom, the struggle against imperial powers and terrorism, which come to the forefront in President Erdoğan's discourse, point to nationalist discourse. These discourses, together with the reactionary structure of Turkish nationalism and the instinct to protect the state, are shaped by the impact of the July 15 Coup Attempt.

Keywords: Nationalism, 15 July Coup Attempt, President Erdoğan, Discourse Analysis, State

\section{Giriş}

Bütün ideolojiler gibi modernitenin bir ürünü olan milliyetçilik, Fransız İhtilalinden beri dünya siyasetinin en temel belirleyicisi, toplumsal hareketlerin dinamiği ve ulusların üzerine inşa edildiği temel düşünce biçimi olmuştur. Her toplumun millet olma ve milliyetçilik deneyimleri farklı olmakla birlikte bu ideoloji genellikle kriz dönemlerinin en görünür aktörü olduğu söylenebilir. Toplumsal çatş̧malar, savaşlar, işgaller ve radikal değişim veya dönüşüm süreçlerinde belirgin bir şekilde varlığını hissettiren milliyetçilik, insanların, hükümetlerin ve devletlerin varlıklarını devam ettirebilmek için sarıldıkları bir güvenlik simidi olma hüviyetine sahiptir. Türkiye özelinde düşünülecek olursa, modern Türk tarihinde de kriz dönemleri ve bu minvalde milliyetçiliğin bu süreçlerde yakaladığ ivmenin etkisi bariz bir şekilde görülmektedir. $\mathrm{Bu}$ krizlerin en sonuncusu, belki de Cumhuriyet tarihindeki en önemlisi 15 Temmuz gecesi yaşanan hain darbe ve işgal girişimidir. Fetullahçı teröristler tarafından organize edilen darbe girişimi, devletin içindeki vatansever sivil ve asker bürokratların yoğun çabaları ve Türk milletinin devletine sokaklarda sahip çıkmasıyla başarısızlığa uğratılmıştır. Türk ordusu içine sızmış Fetöcü asker ve yine bu terörist örgütün sivil darbecilerine karşı, çatışmayı, tankların altına yatmayı ve şehit olmayı göze alarak mücadele eden Türk milleti, devletiyle birlikte demokrasisini ve milli egemenliğini korumuştur. Darbe gecesi bayraklarıyla sokaklara çıan insanlar, darbeden sonra da tekrardan darbe olma olasılığına karşı devletin koruma içgüdüsüyle aylarca sokaklardan ayrılmamışlardı. Bu sürecin baskın düşünce biçimi milliyetçilik olmuş, bayrak, vatan, ezan gibi kavramlar söylemlerde ön plana çıkartılmış, Mustafa Yıldızdoğan'ın seslendirdiği “Ölürüm Türkiyem" şarkısı her yerde duyulur olmuş, darbe girişiminin kahraman ismi Şehit Ömer Halis Demir'in ismi yeni doğan çocuklara verilmiş ve devlet eliyle milliyetçilik dolaşıma sokulmuştur. İşte bu çalışmanın amacı, Cumhurbaşkanı Erdoğan'ın darbe girişiminden sonra muhalefet liderleriyle ve bütün toplum kesimlerinin katıldığı Yenikapı Mitinginde yaptığ 1 konuşmanın milliyetçi retorik çerçevesinde analizini gerçekleştirmektir. Bu analizde milliyetçi öğelerin kullanımı ve Türk milliyetçiliğinin hangi öğesinin baskın olduğu bulunmak istenmektedir. Bu yüzden mevcut çalışmanın metodolojik çerçevesini söylem analizi oluşturacaktır. Bunun dışında mevcut çalışmada sırasıyla, milliyetçilik, Türk milliyetçiliği, 15 Temmuz Darbe ve İşgal Girişimi hakkında bilgi verilecek, daha sonra Cumhurbaşkanı Erdoğan'ın Yenikapı'da yaptığı konuşma Teun Van Dijk'in söylem analizi metoduna göre incelenecek ve sonuç bölümünde çalışmada cevabı aranan sorular tartışllacaktır. 


\section{Metodolojik Çerçeve}

Mevcut çalışmanın metodunu söylem analizi oluşturmaktadır. Söylem analizi, nitel araştırma yöntemlerinden biri olup, postmodern, postyapısalcı ve yorumsamacı yaklaşımlar arasında günümüzde en çok kullanılan yöntemlerden biridir. Wodak’a (2009) göre söylem, belli bir sosyal vaziyette iletişimi sağlayan bir spesifik dilin kullanımı ve sosyal etkileşimdir. Dijk'e (2008) göre söylem, metinler bütünü olup, metinlerin yazılı, söylemlerin de sözlü olması gerekmemektedir. Dijk, karmaşık bir anlamı ihtiva eden söylem olgusunu şu şekilde sinırlamaktadır: kelimelerle ifade edilen kavramlar, cümlecikler ve cümleler ile ifade edilen önermeler, cümle dizileriyle ifade edilen tutarlı önerme dizileri, söylem parçalarının genel anlamları (konular, makro yapılar), (çeşitli bölümler) ve bütün söylemler. Söylem, bir meta eylemdir ve ideoloji, bilgi, diyalog, anlatım, beyan tarzı, müzakere, güç ve gücün değişimiyle eyleme dönüşen dil pratiklerine ilişkin süreç ve ya süreçler koalisyonudur. Söylem, politik, kültürel, ekonomik ve sosyal hayatın bütün yönleri ile bağlantılıdır (Ekşi ve Çelik, 2008, s. 100). Söylem analizi, metin ve ya konuşma biçiminde kullanılan dilin detaylı analizidir. Bu yaklaşım diyalektik olarak birbirine bağlı, dilin sosyal hayatın indirgenemez bir parçası olduğu varsayımına dayanmakta, sosyal yaşamın diğer unsurları, sosyal analiz ve araştırmaların gerçekleştirilmesinde daima dili hesaba katmasını içermektedir (Fairclough, 2003). Sosyal bilimcileri ilgilendiren soru ve konulara uygulanan söylem analizi teorisi ve pratiği, birçok insanın yazısından etkilenmiştir. Ludwig Wittgenstein, John Austin, Roland Barthes, Michel Foucault ve Jacques Derrida gibi bilim adamlarının dile felsefi katkıları ve Kenneth Gergen, John Shotter, Rom Harré'nin geliştirdiği biliş, benlik ve duygu gibi geleneksel psikolojik kavramların teorik eleştirileri, diğerleri arasında, dil hakkında yeni düşünme yöntemlerinin geliştirilmesi ve insanların bunu nasıl kullandıklarını ve ampirik araştırmalar için yeni analitik araçları geliştirmeleri için zengin bir fikir kaynağı sağlamaktadır (Potter ve Wetherell, 2011, s. 60). Söylem analizinin farklı türleri bulunmakla birlikte, burada Eleştirel Söylem Analizi tekniği kullanılacaktır. Eleştirel söylem analizi, söylemi oluşturan, politik ve kültürel bağlamın analizine içkin bir yaklaşımdır. Kimlik, farklılık ve öteki gibi kavramları incelemesi sebebiyle geniş bir çerçeveye sahip olan bu yöntem, şu iki öğeyi içermektedir: siyasal ve sosyal olana ilişkin ve kültür, kültürlerarası etkileşim ve cinsiyet konularındaki eleştirel bakış açısı ile söylem ve eylem arasındaki etkileşim (Yalçıner, 2011, s. 11). Eleştirel söylem analizi için önemli olan metinlerin nedensel etkilerinden biri, ideolojik etkilerdir - metinlerin ideolojileri telkin etme, sürdürme veya değiştirme konusundaki etkileri bu minvalde sayılmaktadır. İdeolojiler, dünyanın güç, tahakküm ve sömürü ilişkilerini kurmaya, sürdürmeye ve değiştirmeye katkıda bulunabileceği yönlerini temsil eder. İdeolojik temsiller metinlerde tanımlanabilir, ancak söyleyerek, ideolojilerin toplumsal güç ve tahakküm ilişkilerine katkıda bulunabileceği söylenebilir. Metin analizinin bu bağlamda metin gövdelerini güç ilişkileri üzerindeki etkileri açısından değerlendirebilecek sosyal analizde çerçevelendirilmesi gerekmektedir. Dahası, eğer ideolojiler temel olarak temsiller ise, yine de sosyal olarak hareket etme biçimleriyle yasalaştırılabilir ve sosyal kurumların kimlikleriyle ilişkilendirilebilir (Fairclough, 2003).

Eleştirel söylem analizinin içinde birçok farklı analiz yöntemi bulunmaktadır. Bu çalışmada, Teun A. Van Dijk'in politik-bilişsel söylem analizi yöntemi esas alınacaktır. Siyasi biliş çalışmaları, 'siyasi bilgi işlemenin' çeşitli yönlerine odaklanmaktadır. Esasen siyasi durumlar, 
olaylar, aktörler ve gruplar hakkındaki zihinsel temsillerin edinimi, kullanımı ve yapılarılla ilgilenmektedir. Politik biliş araştırmalarının tipik konuları şunlardır: politik inançların organizasyonu, siyasi adayların algısı, siyasal yargı ve karar verme, klişeler, önyargılar ve diğer sosyopolitik tutumlar; siyasi grup kimliği; kamuoyu; izlenim oluşumu ve hafıza temsilleri ve siyasi anlayış ve etkileşime dâhil olan zihinsel süreçlerle ilgilenen birçok başka konu yer almaktadır. Politik söylem, bağlam ve politik söylemi oluşturan yapıların -konu, taslak, yerel anlamlar, stil ve retorik- semantik, yani söylemin anlamına dayalı olarak çözümlenmesini esas almaktadır. Genel olarak, o zaman, politik söylemin anlamları ve biçimleri, olay modellerinden ya da her iki durumda da bağlam modellerinin bir işlevi olarak bilgi, tutum ve ideolojiler gibi genel siyasi temsillerden kaynaklanmaktadır. Bilişsel analiz, politik söylemin politik süreçteki rolünü nasıl ifade ettiğini ve oynadığını ayrıntılı olarak açıklamak için esas oluşturmaktadır. Yani, siyasi metin ve konuşma, ani siyasi bağlam ve vesile ile ilgilidir. Sadece sosyal veya politik değil, bireysel metin ve konuşma olarak kişisel özellikleri de içerir. Bir yandan bilişsel bir teori, sosyal ve kişisel arasındaki, yani bir yandan epizodik zihinsel modeller ile diğer kişisel temsiller arasındaki ilişkilerle, diğer yandan grupların sosyal olarak paylaşılan siyasi temsilleri arasındaki ilişkiyi ortaya koyabilir. Politik gruplar ve ya kurumlar böylece yalnızca sosyo-politik olarak etkileşimde bulunan aktör veya kollektiflik kümeleri ve etkileşimleri açısından değil, aynı zamanda sosyo-bilişsel olarak paylaşılan bilgi, tutum, ideolojiler, normlar ve değerler açısından tanımlanır (Dijk, 2002).

\section{Milliyetçilik Literatürüne Kısa Bir Bakış}

Milliyetçiliğin, Batı Avrupa'da başlayan Sanayi Devrimi ve onun neticesinde vuku bulan kapitalizm, kentleşme, kültürün laikleşmesi, okur-yazarlık oranının yükselmesi ve ulaşımiletişim imkânlarının artışına müteakip yaşanan modernleşme süreçleri sonunda ortaya çıkan bir ideoloji olduğu söylenebilir (Schulze, 2005, s. 145-146). Milliyetçiliğin doğuşu ve bir ideoloji olarak biçimlenmesindeki en önemli olay 1789 Fransız İhtilali'dir. Fransız İhtilalinin getirmiş olduğu, günümüzde hala modern devlet sisteminin temel parametrelerinden biri olan milli egemenlik ilkesinin kaynağı olarak işaret edilen self-determinasyon olgusu, insan topluluklarının millete dönüşmesinde, ulus-devletlerin kurulmasında ve bunların bağımsız birimler olarak uluslararası sistemin temel aktörü olmasındaki yegâne kavram olması itibariyle ehemmiyet arz etmektedir. İlk etapta, tebaa olan insan topluluğunu millete dönüştüren ve bu anlamda siyasal iktidarların meşruiyetinin temel dayanağı haline gelen bu kavram, daha sonra ayrilıkçı hareketlerin ve irredentist hedeflerin temel meşrulaştırma araçsalı olmuştur (Keitner, 2007). Milliyetçiliğin ilk biçimi, devrim Fransa'sının etkisiyle daha çok normatif ve liberal tonlar taşımasına rağmen, yine aynı ülkenin, yani Napolyon yönetiminin devrim ilkelerini çiğnemesi ve revizyonist politikaları nedeniyle militarist bir karaktere büründüğü görünmektedir (Keitner, 2007). Napolyon Savaşlarının etkisi altında Alman romantizminin ortaya çıkışı akabinde Alman ve İtalyanların ulusal birliklerini gerçekleştirmelerinden sonra milliyetçilik önemli bir değişim süreci içine girdi. Özellikle 1870-1914 yılları arasında milliyetçiliğin, selfdeterminasyon ilkesinin ayrılıkçı hareketler tarafından benimsenmesi, milli kimlik inşalarında etnisite ve dilin ön plana çıkması ve proleter hareketlere karşı sağ siyasete eklemlenme nedeniyle günümüzdeki nitelikleri şekillenmiştir (Hobsbawm, 1993, s. 126). Birinci Cihan Harbine giden süreçte, milliyetçiliğin ortaya çıktığı ilk zamanlardaki siyasal-sivil yapısı ve vatandaşılı esasına 
dayalı kimlik anlayışı yerini millet olgusunu kan, kültür, dil ve etnisite temelinde tanımlayan etnik milliyetçiliğe bırakmıştı. $\mathrm{Bu}$ anlayışın temelinde, modern Avrupa düşüncesinin merkezinde bulunan biyolojik Darwinizm ve Alman romantizminin doğurduğu etnisist milliyetçiliğin Doğu Avrupa toplumlarını etkisi altına alması bulunmaktadır. Bütün bu gelişmeler Avrupa'nın yeniden Otuz Yıl Savaşlarının ${ }^{2^{*}}$ yaşamasına neden olmuş, bu esnada milliyetçilik Nazizm ve Faşizme eklemlenmişti. Savaşı liberal ABD ve Komünist SSCB bloğunun kazanmasından sonra, galipler arasında başlayan ve SSCB'nin çöküşüne kadar devam eden süreçte, kısacası Soğuk Savaş’ta, milliyetçilik geleneksel yapısından soyutlanarak komünizme eklemlenmiş, anti-kolonyal ve anti-emperyalist hareketlerin biricik ideolojisi haline gelmişti. Ayrıca sosyalist milliyetçiliğe karşı SSCB'nin yayılmacı politikalarına tepki gösteren ve antikomünist saikle hareket eden milliyetçilikler bu dönemde görülmektedir. Soğuk Savaşın sona ermesinden sonra post-Sovyet coğrafyada etnik-dini çatışmalar alevlenerek yeniden etnik milliyetçiliğin güçlenmesini sağladı (Schöpflin, 2001, s. 226-228). Günümüzde ise, Asya, Afrika, Ortadoğu ve Kafkasya'da etnik, dini ve mezhebi çatışmalar tarafından biçimlendirilen milliyetçilikler ile gelişmiş Batılı kapitalist devletlerde görülen, çıkış noktasını göçmen ve İslam karşıtlığının oluşturduğu İslamofobia üzerinden tanımlanacak şekilde ırkçllığın yükselişte olduğu söylenebilir. Burada, küresel güçler arasında yaşanan hegemonya mücadelesi, ekonomik rekabet ve yabancı düşmanlığı -zenofobi- gibi faktörlerin 21. yüzyılda milliyetçiliği temel niteliklerini oluşturduğu ifade edilebilir.

Milliyetçilik, akademik literatürde geniş bir yer kaplayan ve üzerinde mutabık kalınan bir tanımı olmayan kavramdır. Bu yönü itibariyle milliyetçiliğin tanımlarından ziyade temel niteliklerine kısaca bakmak gerekir. Milliyetçilik, teorik yönü zayıf ancak siyasi pratik olarak güçlü bir ideolojidir. Milliyetçiliğin küresel anlamda, Marksizm ya da Liberalizmde olduğu gibi, ideologları bulunmamaktadır, her milliyetçiliğin kendine ait bir seçkin grubu ve kalemleri edebiyatçı, tarihçi ve yazarlar- vardır. Bunlar, kendi toplumlarında milliyetçiliğin kurucuları değil, sadece milliyetçiliğe kendi rengini veren kişilerdir. Milliyetçiliğin en temel niteliklerinden biri programatik içerikten yoksun olmasıdır, bu durum milliyetçiliğin geniş halk kitlelerine ulaşmasında ve büyük destek görmesinde etkili olabildiği gibi, muğlak ve tanımlanmasının zor bir olgu olmasını da beraberinde getirmektedir. Aynı zamanda bu nitelik, milliyetçiliğin her toplumda farklı bir içerikle doldurulmasına neden olmaktadır. Yani milliyetçilik, her toplumda, o toplumun nitelikleri çerçevesinde şekillenmektedir. Doğal olarak bu durum, milliyetçiliğin sabit, evrensel ilkelerinin olamayacağını işaret etmektedir. Bir söylem koalisyonu olan milliyetçiliğin en temel niteliği başka ideolojilerle eklemlenmesi ve bu çerçevede kendi ilkelerini, eklemlendiği ideolojiye göre inşa etmesidir. Milliyetçiliğin farklı ideolojilere eklemlenmesi, her toplumda birden fazla milliyetçilik tasavvurunun da ortaya çıkmasına zemin hazırlamaktadır (Kerestecioğlu, 2016, s. 309-310). Bunların dışında milliyetçilik kendisini politik ve apolitik davranış biçimleriyle ifade edebilmektedir. Politik davranış biçimi, milliyetçi siyasal partilere ve sivil toplum kuruluşlarına destek vermek şeklinde kendisini göstermekte, apolitik davranışlar ise hayatın hemen hemen her alanında milliyetçiliğin kendisini sürekli

\footnotetext{
2 1618-1648 yılları arasında yaşanan, ilk olarak Protestanlık ve Katoliklik davaları üzerinden Alman iç savaşı olarak başlayan ve daha sonra bütün Avrupa kıtasına yayılarak günümüzde hâkim devlet paradigması ulus-devlet anlayışının temellerini atan Westfalya Barışı (1648) ile sona eren savaşın adıdır.
} 
üretimiyle gerçekleşmektedir (Kellas, 1998). Milliyetçilik, çeşitli semboller ve söylemler üzerinden kendisini sürekli üreterek yenileyebilme niteliğine haizdir. Milli Marş, bayrak, ulusal lider kültü, milli semboller vs vasitasıyla milliyetçiliğin her gün yeniden üretilmesine Banal milliyetçilik denilmektedir (Bilig, 2002). Son olarak milliyetçiliğin bir diğer özelliğinden daha bahsetmek gerekir. Milliyetçilik, her toplumda temelde bir olgu, olay, ya da soruna karşı yürütülen politik bir ideolojidir. Geçmişte, Avrupa'da kilisenin üstünlüğüne, eski rejime, enternasyonalist Komünizme, modernleşme hareketlerine, Batı emperyalizmine ve işgalci güçlere karşı yürütülen milliyetçi politikaların tepkisel bir yönü bulunmaktadır. Ancak sadece milliyetçiliğin bir tepki hareketi olarak anlaşılmaması elzemdir, zira diğer ideolojilerle eklemlenerek kuramsal bir zemin inşa edebilmektedir (Delannoi, 1998, s. 33).

Milliyetçiliğin en temel vurgusu millet kavramıdır. Milliyetçi ideoloji bu kavram üzerine inşa edilmektedir. Şahin'e $(2007$, s. 6.) göre milliyetçi fikriyat, politik ve toplumsal yaşamın merkezine millet olgusunu yerleştirmekte, hem toplumsal homojenitenin sağlanmasında, hem de siyasal ve sosyal bütünlüğün gerçekleştirilmesinin en önemli aracı olmaktadır. Kohn (1960, s. 14) ise millet olma bilinci olarak tanımladığı milliyetçiliğin en büyük hedefinin millet inşa etmek olduğunu belirtmektedir. Benzer bir yaklaşımı Smith (2001, s. 223) dile getirmekte; günümüzde milliyetçiliğin şu beş kullanım biçimi olduğunu belirtmektedir: (1) Uluslara ait bir doktrin ya da ideoloji, (2) Ulus ve onun vatandaşlarına ait bir hareket, (3) Ulusa ait dil ve ya söylem ve sembolizm, (4) Ulus adına bir duygu ve (5) Uluslaşmaya ilişkin süreçler bütünü. Millet ve milliyetçilik arasındaki bu ilişki, milliyetçilik literatüründe kuramsal tartı̧maların ortaya çıkmasına neden olmuştur. Milletler mi milliyetçiliği yaratmıştır yoksa milliyetçilikler mi milletleri? Sorusu etrafında şu üç milliyetçilik kuramının şekillendiği görülmektedir: İlkçi, Modernist ve Etno-Sembolist kuram. İlkçi kurama göre milletler, doğal-verili bir kategori olarak insanların doğumla kazandığı ve tarihin çok eski devirlerine dayanan yapılardır. Dolayısıyla milliyetçilik milletler tarafından oluşturulmuştur ve her ikisi de çok eski olgulardır. Modernist kurama göre milletler ve milliyetçilikler, sanayileşme, kentleşme ve kapitalizm gibi modern süreçlerin sonunda ortaya çıkan kavramlar olup, milliyetçilikler milletleri inşa etmişlerdir. Her iki yaklaşımın arasında bir üçüncü yol olarak Etno-Sembolist kuram, milletler ve milliyetçilikleri modernite sonucunda ortaya çıktıklarını kabul etmekle birlikte milletlerin, tarihi kökenleri bulunan etni denilen topluluklara dayandığını iddia etmektedir (Özkırımlı, 2009).

Milliyetçilik, literatürde çok fazla tartışılmasına rağmen üzerinde mutabık kalınmış tanımı olmayan bir olgusudur. Daha önce de belirtildiği üzere bu milliyetçiliğin niteliklerinden kaynaklanan bir durumdur. Ancak bu çalışmada milliyetçiliğin bir tanımını belirleyip, o tanım temelinde hareket etme ihtiyacı görülmektedir. Böylece bu çalışmada milliyetçilik, Calhoun'un yaklaşımından hareketle bir söylem olarak kabul edilecektir. Söylem olarak milliyetçilik Calhoun (2012, s. 7) tarafından şu şekilde tanımlanmaktadır: "Dünyanın her yerinde insanları, özlemlerini ulus ve ulusal kimlik bağlamında düşünmeye ve o çerçeve içine yerleştirmeye götüren kültürel anlayışın ve retoriğin üretimiyle belli ortam ve geleneklerdeki belli milliyetçi dil ve düşünce türlerinin üretimi”. Bu tanım, milliyetçiliği, tek ya da birkaç faktör üzerinden tanımlamaya çalışan yaklaşımların aksine bütüncül bir çerçevede değerlendirilmesine ve 
bütüncül bir yaklaşım sunması bakımından işlevsel görülmektedir. Ayrıca milliyetçiliğin bir söylem olarak kabul edilmesi, mevcut çalışmanın metodolojik çerçevesiyle de uyumlu bir yaklaşım oluşturmaktadır.

\section{Türk Milliyetçiliği: Temel Nitelikler ve Dönüşümler}

Türk milliyetçiliği, 19. yüzyllın sonunda, Osmanlı İmparatorluğu'nda meydana gelen politik, iktisadi, kültürel ve sosyolojik değişim ve dönüşümlerin neticesinde ortaya çıkan yeni bir anlam dünyasına dayalı olarak doğmuş bir fikir hareketidir. Burada, Türk milliyetçiliğini teferruatlı bir şekilde incelemek, çalışmanın kapsamı dışında olmakla birlikte temel niteliklerine ve geçirdiği dönüşümlere kısaca bakmak gerekmektedir. Türk milliyetçiliğinin üç temel niteliği bulunmaktadır. Bunlardan ilki, Osmanlı İmparatorluğu döneminde en geç ortaya çıkan milliyetçilik, Türk milliyetçiliğidir. İslamiyet, İmparatorluk yapısı ve Türk burjuvazisinin bulunmayışı, geç bir dönemde ortaya çıkışın temel nedenleri olarak sayılabilir. İkinci olarak, Türk milliyetçiliği bir tepki hareketidir. Osmanlı'nın son dönemlerinde yaşadığı mağlubiyetler, etnik, dini ve mezhebi azınlıkların isyanları, Batı’nın çifte standartları ve saldırganlığı, Türklere yönelik katliamlar ve Müslüman grupların milliyetçilikleri Türkler arasında bir reaksiyonun doğmasina neden olmuş ve bu durum kendisini milliyetçilikle ifade etmiştir. Üçüncü ve son olarak, Türk milliyetçiliği, yıkılmakta olan bir İmparatorluğu nasıl ayakta tutabiliriz? Sorusunun son cevabı-Osmanlıclık ve İslamcılıktan sonra- olarak, asker ve sivil bürokrasinin öncülüğünde devlete dayalı bir ideoloji olarak ortaya çımasıdır (Bölükbaşı, 2019, s. 67-70). Özellikle Türk milliyetçiliğinin reaktif yapısı ve devletin varlığını devam ettirme saikiyle hareket etmesi, Osmanlı'dan günümüze devam eden en temel karakteristik özellikleridir.

Türk milliyetçiliği, İttihat ve Terakki Cemiyetinin iktidarının son evresinde devletin resmi ideolojisi haline gelmiş, bu durum Cumhuriyetin kuruluşuyla da devam etmiştir. Mustafa Kemal Atatürk'ün, modern Türkiye Cumhuriyetini kurarken benimsediği ve daha sonra Cumhuriyet Halk Partisinin altı oku olarak belirlediği ilkelerden biri olan Türk milliyetçiliği, geleneksel Osmanlı Türkçülüğünden daha farklı bir karaktere bürünmüştü. Bu durum, Türk milliyetçiliğinin farklı tipolojilere ayrılmasının ilk örneğini oluşturmaktaydı. Devletin resmi ideolojisi haline gelen milliyetçilik anlayışı, Kemalist ya da Resmi milliyetçilik olarak isimlendirilmektedir. Cumhuriyetin ilk yıllarında sivil-siyasi kimlik tasarımıla ön plana çıkan bu tasavvur, 1930'lu yıllarda etno-seküler bir nitelik kazanmıştı (Yıldız, 2013, s. 124-126). Sacayaklarını Türk Tarih Tezi ve Güneş Dil Teorisinin oluşturduğu ve amacı Batıll-seküler bir kimlik inşa etmek olan Kemalist milliyetçilik (Çağaptay, 2009) saf halini II. Cihan Harbi dönemine kadar korumuştur. Savaşa giden süreçte Türk milliyetçiliği kendi içinde bir yol ayrımına gitmiş, resmi ideolojinin pragmatist uygulamalarının yanı sıra, tarih tasavvuru, kimlik paradigması, dış politika anlayışı ve medeniyet algısı, başta Hüseyin Nihal Atsız olmak üzere bazı Türkçüler tarafından eleştirilmiş ve bu noktada soy esasına dayalı Türkçü-Turancı milliyetçilik anlayışı gelişmiştir (Bölükbaşı, 2018, Yücel ve Bölükbaşı, 2019). Türkçü-Turanc1 milliyetçilik, her ne kadar Resmi ideoloji tarafından mahkemeler -politik davalar- vasitasıyla ötekileştirildiyse de, açtı̆̆ muhalefet kulvarı üzerinden ve anti-komünist söylemleri vasitasıyla Türkçülüğü siyasetin sağ yelpazesine yerleştirmesiyle yeni bir milliyetçilik tipolojisinin doğuşuna zemin hazırladı. Soğuk Savaş konjonktürü ve Komünizmle mücadele saikiyle hareket 
eden, İslamiyet ve Türklüğü tekrar bir araya getirerek bir nevi Osmanlı dönemindeki geleneksel milliyetçiliğin yeniden ihdası olarak yorumlanabilecek olan bu anlayış, "Türk-İslam Ülküsü" şeklinde nitelendirilebilecek muhafazakâr milliyetçilik anlayışıdır. Özellikle Osmanlı tarihine bakış ve İslamiyet noktasında diğer milliyetçilik türlerinden ayrılan muhafazakâr milliyetçilik (Ayvazoğlu, 2009, s. 577), çeşitli dernekler, dergiler ve ideologların katkısıyla biçimlenmiş, Milliyetçi Hareket Partisi bunun neticesinde otaya çıkmış ve Türk milliyetçiliği, hem toplumsallaşabilmiş, hem de siyasallaşabilmiştir (Bölükbaşı, 2019, s. 96-102). MHP’nin temsil ettiği bu milliyetçilik anlayışı, Partinin kurucusu ve Genel Başkanlığını 1997 yllına kadar sürdüren Alparslan Türkeş’in "Türklük bedenimiz, İslamiyet ruhumuzdur, ruhsuz beden ceset olur" (mhp.org.tr) sözüyle vücut bulmaktadır. Böylece Türk milliyetçiliğinin temel damarları şekillenmiş olmaktadır.

Türkiye'de Türk milliyetçiliğinin yegâne aktörü MHP'dir. Çünkü MHP ideolojisinin merkezine milliyetçiliği yerleştirmiş, söylem ve davranışlarını buna göre şekillendirmiştir. Bunun dışında Türkiye'de milliyetçilik, neredeyse bütün akımlar tarafından, toplumsallaşabilmek ve başarıya ulaşmak için kullanılmaktadır. Bu durumu Belge (2003), "Yahudi anne" metaforuyla açıklamakta, Türkiye'de milliyetçiliğin Yahudi anne olduğu, onun eteklerine yapışan çocuklarının da muhafazakârlık, liberalizm, sol, İslamcılık ve Kemalizm olduğunu belirtmektedir. Bu çalışmada da, Adalet ve Kalkınma Partisinin kurucusu ve Genel Başkanlık görevini yürüten Cumhurbaşkanı Recep Tayyip Erdoğan'ın söylemleri inceleneceği için kısaca AK Partinin milliyetçiliğe ilişkin yaklaşımına kısaca bakmak yararlı görülmektedir. AK Parti, merkez sağ partisi olmakla birlikte Milli Görüş kökeninden gelen karar vericileri bulunması sebebiyle İslamcı bir yön de taşımaktadır. Bu iki akımın çeşitli açılardan milliyetçiliğe eklemlenmesi ya da milliyetçilikle olan simbiyotik ilişkileri sebebiyle Parti karar vericilerinin söylemlerinde milliyetçilik görülmektedir. İlk başta, milliyetçi söylemin tam zıttı olan ifadeler karar vericilerin retoriklerinde yer alırken, ilerleyen dönemlerde bu durumun tersine döndüğü anlaşılmaktadır. Akademik literatürde, özellikle 15 Temmuz süreci öncesi için AK Partinin milliyetçilik yaklaşımını İslam milliyetçiliği (White, 2013, Aktürk, 2012, Maessen, 2014), İslami-muhafazakâr milliyetçilik (Saraçoğlu, 2013) Neo-Osmanlıcı milliyetçilik (Dönmez, 2015) ve Neo-liberal muhafazakâr milliyetçilik (Özkırıml, 2013) şeklinde tanımlandığı görülmektedir. Bu konuyla ilgili genel bir değerlendirme yapılacak olursa, 15 Temmuz süreci öncesinde, neo-liberal tandansa sahip, İslami kısmı Türklük kısmından daha ağır basan bir milliyetçilik tasavvuruna sahip olduğu söylenebilir. Kavramsal olarak muhafazakâr milliyetçiliğin bir alt dalı olan İslami-Anadoluculuk şeklinde tanımlanabilir (Bölükbaşı, 2019, s. 289-290). Ancak 15 Temmuz Darbe ve İşgal girişimi, akabinde gerçekleştirilen Furat Kalkanı, Zeytin Dalı ve Barış Pınarları operasyonları, başta $\mathrm{ABD}$ olmak üzere küresel güçlerle yaşanan gerilimler ve terör örgütlerine -Fetö, PKK, Daeş ve Dhkp-c- karşı yürütülen kararlı operasyonlar, Türkiye'de milliyetçiliğin siyasal ve toplumsal bağlamda yükselmesine neden oldu. Siyasal anlamda MHP ve AK Parti arasında kurulan Cumhur İttifakı, girdikleri bütün seçimlerden -16 Mart 2017 Anayasa Referandumu, 24 Haziran 2018 Genel Seçimleri ve 31 Mart Yerel Seçimi- zaferle ayrıldılar. Bu çalışmada, Cumhurbaşkanı Erdoğan'ın 15 Temmuz konuşmaları üzerinden söylem analizi vasıtasılla milliyetçiliğin hangi niteliğinin ön plana çıktı̆̆ incelenerek tartışılacaktır. 


\section{Temmuz Darbe ve İşgal Girişimi}

15 Temmuz Gecesi yaşanan, TSK içine sızmış Fetullahçı teröristler tarafından gerçekleştirilen darbe ve işgal girişimi hadisesi, Türk tarihinin en önemli dönüm noktalarından biri olduğu ifade edilebilir. Aslında Türk siyasi tarihi incelendiğinde birçok darbe olduğu -1960, 1971, 1980 ve 28 Şubat 1997- ve bunların devleti zayıflattığı görülmekte, Türkiye Cumhuriyeti için birere kara leke oldukları kabul edilmektedir. Ancak 15 Temmuz Darbe ve İşgal girişimi, bundan önce yaşanan darbelerden nitelikleri itibariyle farklılaşmaktadır. Bu minvalde, sivillere doğrudan ateş açılıp şehit edilmeleri, TBMM ve Cumhurbaşkanlığı Külliyesinin F-16 vasıtasıyla bombalanmaları, Cumhurbaşkanı Erdoğan'ı doğrudan öldürmeyi hedeflemeleri, başka terör örgütleri -PKK- ile birlikte ittifak yapılması suretiyle ülkeyi işgal etmeyi planlamaları ve kendi kimliklerini gizlemeleri -darbe gecesi Atatürkçü olduklarını iddia etmeleri- gibi nitelikler zikredilebilir. Burada öncelikle 15 Temmuz'a giden süreci, daha sonra o gece yaşananlara kısaca bakmak yararlı görülmektedir.

Fetullahçı terör örgütü, geçmişi 1960'lı yıllara dayanan, o tarihten itibaren bürokrasi, iş dünyası, emniyet ve TSK içinde, kimliklerini gizlemek suretiyle yapılanan uluslararası bir terör örgütüdür. İki binli yılların başından itibaren yaşanan bir takım hadiseler, bu terör örgütünün Türkiye'yi işgal çalışmalarının parçaları olması hasebiyle önem arz etmektedir. 2005 yılında Şemdinli Olaylarıyla TSK içindeki Fetöcü olmayan subayların tasfiye edilmeye başlaması, sürecin ilk basamağını oluşturmuştur. 2006 yılında Trabzon'da yaşanan Rahip Santoro cinayeti ve yine aynı yıl gerçekleştirilen Danıştay saldırısıyla bu süreç devam ettirilmiştir. 2007 yılında Malatya'da vuku bulan Zirve Yayınevi katliamı ve Agos Gazetesi yazarı Hrant Dink cinayeti, ordudaki tasfiye planının devamı niteliğindedir. Ancak bu yıl yaşanan bir olay, Fetöcülerin planlarını iyice açığa çıkarması bakımından ehemmiyet arz etmektedir. Bu, Ergenekon Operasyonları vasıtasıyla gerçekleştirilen, ordu, bürokrasi ve sivil toplum kuruluşlarını etkileyen bir takım tutuklamalar ve Fetöcü olmayanların bu alanlardan dışlanmaya çalışılması hadisesidir. Bunun cisimleştiği olay, 2010 Balyoz Davası oldu. Sahte deliller, gizli tanıklar ve uydurma ifadelerle çok sayıda subay, bürokrat ve aydın tutuklandı. Bülent Arınç'a suikast yapılacağı, Fatih Camisinin bombalanacağı ve seçilmiş hükümetin darbe ile iktidardan uzaklaştırılacağı ilişkin suçlamalar, bu kişilere yöneltildi. Fetöcüler, gerekli tasfiyelerin yapılabilmesi için Ekim 2010'da HSYK’yı ele geçirdiler. 2011 yılında ise futbol sektörü üzerinden toplumu dizayn etmeye çalışan Fetöcüler, Şike davaları vasıtasıyla Fenerbahçe Spor Kulübüne operasyon düzenlediler. Aynı yılın Şubat ayında Askeri Casusluk Davasıyla ordudaki tasfiye sürecine devam eden Fetöcüler, Mart ayındaki Oda Tv davasıyla, Fetö konusunda toplumu ve devleti uyaran gazeteci Nedim Şener tutuklanmasını sağladılar. Ama 2012 yılının Şubat ayında yaşanan bir hadise, Fetullahçı teröristlerin devletin en kilit kurumunu ele geçirmeye çalışmalarını gözler önüne serdi. MİT Müsteşarı Hakan Fidan, eski Müsteşar Emre Taner ve yardımcısı Afet Güneş, İstanbul Özel Yetkili Savcılığı tarafından şüpheli sıfatıyla ifadeye çağırıldılar. Başbakan Erdoğan bu duruma tepki göstererek Fidan'a kesinlikle savcılığa gitmemesini söyledi. Böylece, Başbakan Erdoğan ve Fetö terör örgütü arasındaki çatışma cisimleşti. Bundan sonraki süreçte Türkiye, üç darbe ile karşı karıya kaldı. İlki, Mayıs 2013'de başlayan Gezi Parkı hadisesidir. Buradaki olayların alevlenmesinde, Fetöcü polislerin göstericilere sert müdahaleleri ve yaklaşımları olmuştu. Bunu, 17-25 Aralık Yargı-Ekonomi 
Darbesi izledi. En nihayetinde, 2016 yılında Yüksek Askeri Şura'da çok sayıda Fetöcü subayın ordudan uzaklaştırılacağı bilgisine ulaşan teröristler, darbe yapmaya karar verdi ve 15 Temmuz 2016 gecesi bu hain girişim vuku buldu (tccb.gov.tr, 2016, s. 7-11). Burada, 2011 Genel Seçimleri öncesinde MHP’li üst düzey Parti yöneticilerine ve daha sonra CHP Genel Başkanı Deniz Baykal'a yapılan kaset kumpaslarını da eklemek gerekmektedir.

15 Temmuz 2016 Darbe ve İşgal girişimi, gece saat 22.00 sularında Genelkurmay Başkanlığında duyulan silah sesleri ve İstanbul'daki Fatih Sultan Mehmet ve Boğaziçi (daha sonra 15 Temmuz Şehitleri Köprüsü şeklinde adı değiştirilmiştir) köprülerinin darbeci askerler tarafından kapatılmasıyla başlamıştır. Saat 24.00’a gelindiğinde darbe girişiminin TSK içindeki Fetullahçı teröristler tarafından yapıldığı güvenlik kaynaklarınca doğrulanmıştı. 00.13'te darbeciler TRT'yi işgal ederek korsan darbe metnini spikere okuttular. 01.01'de Ankara Emniyet Müdürlügü darbeciler tarafindan savaş uçakları ve helikopterlerce vuruldu. 01.43'te Cumhurbaşkanı Erdoğan, Dalaman havalimanından İstanbul Atatürk havalimanına hareket etti. 02.20'de Ankara'da bulunan Gölbaşı Özal Harekât Daire Başkanlığı ve Türksat darbeciler tarafından savaş uçakları vasıtasıyla vuruldu. Gölbaşında 44 vatan kahramanı Özel Harekâtçı şehit düştü. 02.30'da ise Cumhurbaşkanlığı Külliyesine girmeye çalışan Fetö mensupları gözaltına alındı. 02.42'de ise TBMM bombalandı. 03.00'da TRT'yi işgal eden darbeciler derdest edildi ve TRT kurtarıldı. 03.20'de Cumhurbaşkanı Erdoğan, ilk etapta Fetöcüler tarafından işgal edilen daha sonra kurtarılan Atatürk Havalimanına indi ve halkın sevgi seliyle karşılandı. Ankara Cumhuriyet Başsavcılığı, 04.00'da "Yurtta Sulh Konseyi” üyeleri için yakalama gözaltı çıkarttı. Genelkurmay Başkanı Hulusi Akar, Fetöcüler tarafından esir alındığı için, 06.52'de Birinci Ordu Komutanı Orgeneral Ümit Dündar, Genelkurmay Başkanlığına vekâleten atandı. 07.28'de Üçüncü Ordu Harekât Kurmay Başkanı Tuğgeneral Ekrem Çağlar, Erzincan'da gözaltına alındı. 08. 16'da Boğaziçi Köprüsü darbecilerden temizlenerek kısmen trafiğe açıldı. 08.17'de ise Ege Ordu Komutanlığı Kurmay Başkanı Tümgeneral Memduh Hakbilen, İzmir'de tutuklandı. 08.32'de ise Akıncı Hava Üssüne operasyon yapıldı ve Genelkurmay Başkanı Hulusi Akar kurtarıldı. 08.36'da ise Jandarma Genel Komutanlığı, Özel Harekâtçılar tarafından kurtarıldı. 09.40'da, Eski Hava Kuvvetleri Komutanı Orgeneral Akın Öztürk ve Korgeneral Metin İyidil hakkında vatana ihanet suçundan işlem başlatıldı. Saat 10.07 sularında Genelkurmay Başkanlığından çıkan 700 darbeci silahlarını bırakarak teslim oldu. 10.15'te Tuğgeneraller Yunus Kotaman ve İsmail Güneşer gözaltına alındı. Bundan yaklaşık yarım saat sonra İçişleri Bakanı Efkan Ala, Sahil Güvenlik Komutanı Tümamiral Hakan Üstem’i görevden ald1. 12.04'te Özel Harekât Polisleri, Jandarma Genel Komutanlığı binasında 200 darbeci askeri gözaltına aldılar. Bundan sonra Tuğgeneraller Dursun Pak ve Recep Ünal gözaltına alındılar (tccb.gov.tr, 2018, s. 5). Böylece, 15 Temmuz gece 22.00'da başlayan darbe girişimi, 16 Temmuz öğlen sularında milletin zaferi ve darbecilerin hezimeti ile sona erdirildi.

Fetöcüler tarafından gerçekleştirilen 15 Temmuz Darbe ve İşgal girişiminin başarısız olmasında, dirayetli devlet adamları, bürokratlar, vatansever asker ve polislerin yanında, belki onlardan da daha fazla paya, Türk milleti sahip olmuştur. Darbe gecesi sokağa çıan, darbecilerle çarpışan, darbecilerin belirledikleri hedeflere gitmesini engelleyen ve birçok yerin kurtarılmasında aktif rol oynayan Türk milleti, 15 Temmuz gecesinin en büyük kahramanı 
olduğu söylenebilir. Bu niteliği itibariyle 15 Temmuz Darbe ve İşgal Girişimi, diğer darbelerden ayrılmakta, milletin reaksiyonu ile engellenen bir darbe olarak tarihe geçmektedir. Bu kahramanca mücadelenin sonucunda, 251 kişi şehit, 2190 kişi de gazi olmuştur. Darbe gecesi, 35 askeri uçak, 74 tank, 246 zurhlı araç, 3 askeri gemi, 3992 silah, 37 askeri helikopter ve 10000 darbeci-sivil ve asker- bu hain girişime katılmıştır (tccb.gov.tr, 2016, s. 21).

Darbe girişiminin başarısız olmasının ardından hükümet gerekli tedbirleri almaya başladı. Belli bir dönem OHAL uygulamasına gidildi, KHK'larla binlerce Fetöcü kamu görevinden uzaklaştırıldı ve yargılandı. Günümüzde Fetö ile mücadele devam etmekle birlikte birçok sorun ve tartışma, bu mücadelenin sürdürülmesini akamete uğratmaktadır. Her şeyden önce, Fetö uluslararası bir terör örgütü olup, dünyanın birçok ülkesinde faaliyetlerine devam etmektedirler. Terör örgütü lideri Gülen ise ABD'de ikamet etmekte, başta ABD olmak üzere Türkiye'nin müttefiki olduğunu iddia eden Batılı ülkelerin büyük çoğunluğu ülkelerindeki Fetöcü teröristleri Türkiye’ye iade etmemektedirler. Bunun yanında yurtiçinde siyasi partiler arasında da Fetö konusunda bir konsensüs sağlanamamakta, siyasi hesaplar uğruna Fetö ile mücadeleyi sekteye uğratacak açıklamalar -darbenin tiyatro olduğunun belirtilmesi gibiyapılmaktadır. Fetönün siyasi ayağı tartışması, "Fetö Borsası" vasıtasıyla Fetöcülerin aklandıklarına ilişkin iddialar, KHK mağduriyeti gibi söylemler üzerinden bütün Fetöcülerin mağdur potasına sokmaya çalışılması, Fetöyü açıkça destekleyen bazı yazarların yargı kararları neticesinde serbest kalmaları ve bu durumun kamuoyunun tepkisini çekmesi gibi sayısız neden bu bağlamda dile getirilebilir. Yine Fetullahçı teröristlerin sosyal medya üzerindeki hakimiyetleri, buradan yapılan manipülasyonlar ve Fetöye karşı mücadele edenleri itibarsızlaştırmaya çalışmaları, mücadeleyi güçleştirmektedir. Nitekim Üçok’a göre Fetö hala devletin birçok kurumunda gücünü korumaktadır, özellikle bürokrasi ve üniversitelerde Fetö temizliğinin yeterince yapılmadığını belirtmektedir (www.aydınlık.com). Aynı zamanda Fetö terör örgütünün sahip olduğu bazı niteliklerin de, Fetö ile mücadeleyi zorlaştırdığı görülmektedir. Şener'in (2018) de belirttiği üzere, Fetöcülerin en başarılı olduğu konu, kendi kimliklerini farklı kimlikler altında gizleyerek terörist faaliyetlerine devam edebilmeleridir. Yine de Fetöyle mücadeleye Türkiye Cumhuriyeti kararlı bir şekilde devam etmekte, ordu, bürokrasi, devlet kurumları ve iş dünyasından bu teröristler temizlendikçe, Türkiye güçlenmektedir.

\section{Cumhurbaşkanı Erdoğan'ın 15 Temmuz Darbe ve İşgal Girişiminden Sonra Yenikapı Mitinginde Yaptığı Konuşma ve Analizi}

Cumhurbaşkanı Erdoğan, 15 Temmuz Darbe ve İşgal girişiminin ardından, Yenikapı'da yaptığı konuşmada şunları belirtmektedir (tcbb.gov.tr, 2016):

15 Temmuz gecesi bir kez daha istiklali ve istikbali için kıyam eden, canı pahasına ülkesini Fethullahçı terör örgütüne, işgalcilere teslim etmeyen aziz milletim; Sizleri en kalbi duygularımla hasretle, muhabbetle selamllyorum. Sözlerimin hemen başında 15 Temmuz gecesi sokaklara, meydanlara inerek, havalimanlarm uçakların karşısına dikilme cesareti gösteren tüm kardeşlerime bir kez daha şükranlarımı sunuyorum. Bu kardeşlerimizden 172'si sivil, 63'ü polis, 5'i asker olmak üzere 240'i şehadet makamına ulaştılar. Kendilerine bir kez daha Allah'tan rahmet, yakınlarına başsağlğ̆ı 
diliyorum. Milletimizin başı sağ olsun. Yine o gece kahramanca darbecilerin üzerine yürüyen kardeşlerimizden 2195 tanesi yaralanarak gazilik rütbesine ulaşmıştır. Hastanelerde ve evlerde tedavileri süren yaralılarımıza Rabbimden şifalar niyaz ediyorum. O gece adeta ölümü öldürerek sokakları, meydanları dolduran milyonlarca vatandaşımız içinden şehitlik ve gazilik şerefine laylk olanlar isimlerini tarihe altın harflerle yazdirdılar. İnanin bana vatan uğruna verilen mücadelede bu rütbelere ulaşabilmek her zaman yakalanabilecek, her zaman elde edilebilecek bir ayrıcalık değildir.

Ne diyor İstiklal Şairimiz İstiklal Marşımızda: "Kim bu cennet vatanın uğruna olmaz ki feda, Şüheda fışkıracak toprağı sıksan şüheda, Canı cananı, bütün varımı alsın da Hüda, Etmesin tek vatanımdan beni dünyada cüda."

Kardeşlerim; Bu millet başka bir millet, gerçekten Türk milleti bin yıl önce Malazgirt'te hangi inanç ve kararllikla Anadolu'nun kapıların açmısssa, 15 Temmuz'da da aynı hissiyatla darbecilerin karşısına dikilmiştir. Süleyman Şah 1075 yllında bu coğrafyadaki ilk devletimizi hangi vizyonla kurmuşsa, 15 Temmuz'da da ülkemize aynı vizyonla, aynı ufukla sahip çıtık. Osman Gazi 1299'da tarihin en kudretli devletini hangi temeller üzerine bina ettiyse, biz de o gece Türkiye'yi aynı ilkeler etrafinda müdafaa ettik. Ecdadımız 100 yıl önce hangi idrakle Çanakkale'de kanının son damlasina kadar mücadele ettiyse, 15 Temmuz'da da ayn iradeyle FETÖ'cü terör örgütünü, darbecileri geri püskürttük. Gazi Mustafa Kemal'in İstiklal Harbi’ni başlatmasını ve zafere ulaştırmasını sağlayan inancın bir benzeri, 15 Temmuz'da Türkiye'nin tüm şshirlerinde adeta kol geziyordu. 15 Temmuz dostlarımiza bu ülkenin sadece siyasi, ekonomik, diplomatik saldırılara değil, aynı zamanda askeri sabotajlara karşı da güçlü olduğunu, yıkılmayacağını, rayından çıkmayacağını göstermiştir. Ayn gece Türkiye’nin yerle yeksan olması için ellerini ovuşturarak bekleyen düşmanlarımız ise ertesi güne bundan sonra işlerinin çok daha zor olduğunu görmenin kahriyla uyandılar. Şimdi bugün burada Genelkurmay Başkanıyla, Yenikapı Meydani'nda Cumhurbaşkanıyla, Başbakanıyla, Cumhuriyet Halk Partisi ve Milliyetçi Hareket Partisi genel başkanlarıla 81 vilayetimizdeki her görüsten, her meşrepten insanımızla verdiğimiz şu görüntü var ya, işte bu görüntü, inanın bana ülkemizin düşmanların en az 16 Temmuz sabahı kadar üzmüştür, kahretmiştir. Onun için her zaman ne diyoruz? Bir olacağız, iri olacağız, diri olacağız, kardeş olacağız, hep birlikte Türkiye olacağız. Bu manzara, Türkiye’nin tüm renkleriyle, bağımsızlğına ve geleceğine yönelik atılan bu adımlar var ya, işte bunlar çok önemli. Bu, geleceğe yönelik adeta vatanımıza sahip çıkmanın ilanı ve ispatıdır. Bu manzara, bin yıllık vatanımızın tek bir taşına dahi göz dikenlerin ödemeyi göze alacakları bedelin ilanı ve ispatıdır. Bu manzara Türkiye'nin 2023 hedeflerine ulaşacağının ilanı ve ispatıdır. Bundan sonra işimiz ne biliyor musunuz? Artık muasır medeniyetler seviyesinin üstüne çıkmak. Bunu başarmaya var mıyız? Bu manzara birliğin, beraberliğin, kardeşliğin sadece temenni, sadece slogan değil; gerektĭ̈inde bir hakikat olarak ortaya konabileceğinin, kuvveden fiile geçebileceğinin ilanı ve ispatıdır... Bakınız, Cumhuriyetimizin banisi Gazi Mustafa Kemal 1920 yllında İstanbul ve İzmir başta olmak üzere ülkenin büyük bölümünün işgal altında olduğu o kara günlerde şunu söylüyordu: "Milletimiz çok büyüktür, hiç korkmayalım, o esaret ve zillet kabul etmez. Fakat onu biraraya toplamak ve kendisine; ey millet, sen esaret ve zillet kabul eder misin diye sormak lazımdır." Ben milletimin vereceği cevabı bekliyorum, şimdi burada bir kez daha soruyorum: 
Gazi'den 96 yıl sonra Yenikapı Meydani'ndan aynı soruyu sizlere soruyorum: Ey millet, sen esaret ve zillet kabul eder misin? Mesele bu. Bu millete, evet kimse bu esareti asla getiremeyecektir.

Kardeşlerim; Vatan Caddesi'nde vücudu ikiye bölünmüş kardeşimi gördüğ̈̈m zaman kalkıp da bunu kenara koymak mümkün mü? Ankara'da Cumhurbaşkanlığı Külliyesi önünde uçaktan F16’ların yağdırdığı bomba ile başı vücudundan ayrılmış olan hanım kardeşimin başı Kongre Merkezi'nin çatısına uçmuştu. Bunu gördükten sonra biz kalkıp da, 'Efendim Avrupa Birliği'nde idam yokmuş, Konsey'de yokmuş, şurada yokmuş, burada yokmuş' diyemeyiz. Amerika'da var, büyük bir çoğunluğunda var, Japonya'da var, Çin'de var, bugün dünyanın büyük bir çoğunluğunda var. Burada zaten 84'e kadar vardı, ondan sonra kaldırıldı. Bu millet, 'egemenlik kayıtsız şartsız milletin' olduğuna göre eğer böyle bir kararı veriyorsa, öyle zannediyorum ki siyasi partiler de bu karara uyacaktır. Sizler 15 Temmuz'a esaret ve zillet kabul etmeyeceğinizi namlulara göğsünüzü dayayarak, tanklarm önüne yatarak, uçaklara ve helikopterlere dahi hamleler yaparak bilfiil gösterdiniz. Hani ne diyor İstiklal Marşımızda, "Siper et gövdeni dursun bu hayâsızca akın." Siz göğsünüzü siper ettiniz. Namluların ucuna geldiniz bizzat vücudunuzu koydunuz. Tankların altına yattını. Bakıyorum ki bir gazimiz tankların iki paletinin arasina kendini atıyor, birinci tanktan kurtuluyor, ikinci tankın altına da kendini aynı şekilde atıyor, sadece kolu ciddi manada yaralanıyor. Kendisini telefonla aradığımda söylediği ne biliyor musunuz? 'Siz beni bırakın Cumhurbaşkanım, siz nasılsınız?' diyor. Bu bambaşka bir ruh, bambaşka bir aşk. "İmandır o cevher ki ilahi ne büyüktür, imansız olan paslı yürek sinede yüktür." İmansız olanlar imanlı olanların karşısında dayanamadılar. Bu FETÖ, birçok sinsiliği hesap etti de bir şeyi hesap edemedi. Neydi o? O da bu milleti hesap edemedi. Bu milletin imanın, bu milletin inancını, bu milletin dirayetini o hiç hesaba katmadı. Zannetti ki, zaten bazı bunların akıl daneleri konuşuyor ya, 'Bunlar silahın önüne falan gelmez' diyor. Ne oldu? Hani yetiştirdiğiniz bazı adamlar, Silahlı Kuvvetlerimizin içindeki o bazı hainler? Burada tabii özellikle Türk Silahlı Kuvvetleri'mizin büyük bir çoğunluğunu, vatansever, milliyetperver olan askerlerimizi tenzih ediyorum. Bunu az önce zaten Genelkurmay Başkanımız konuşurken de gösterdiniz. Aynı şekilde Polis Teşkilatımızın içinde... Gerçekten her şeyleriyle vatansever olanlar, milliyetperver olanlar kendilerini ortaya koymasaydılar işimiz çok daha zor olacaktı.

Ne diyor o güzel türküsünde sanatçımız: “Gez oğlum, Vatanına göz dikeni ez oğlum.!, Dostun kim düşmanın kim sez oğlum, Tarihini şerefinle yaz oğlum, Yaz oğlum.!, Senden gider sonsuzluğa yol oğlum, Dört bir yana salmalısın kol oğlum, Ekmeğini aç olanla böl oğlum, Haram yeme, Hak uğruna öl oğlum.!”.

Aziz milletim; Devlet ve millet olarak 15 Temmuz darbe girişimini çok iyi analiz etmeliyiz. Sadece bu ihaneti gerçekleştirenleri değil, onların arkalarındaki güçleri, onları harekete geçiren saikleri de çok iyi değerlendirmeliyiz. Fethullahçı terör örgütü mensuplarının, bunların ismini hala ağzına almaktan çekinenler var. Çekinmeyelim, muktedir olanlar bunların isimlerini aynen ifade etsinler ki bilmeyenler, bu FETÖ'cüler kimdir, bu FETÖ kimdir, Fethullahçı terör örgütü kimdir bunu öğrensin. Ülkemize yönelik tehdidin görünürdeki maşalarıdır. Biliyoruz ki bu oyun, bu senaryo onların boylarını çok aşar. Elbette bu örgütü tüm mensuplarıla ortaya çıkarmak ve hukuk dairesinde imha etmek mecburiyetindeyiz. Ama sadece bununla yetinirsek, devlet ve millet 
olarak bünyemizi benzer virüslere karşı yine savunmuş, savunma noktasında zayıf bırakmış oluruz. Silahlı Kuvvetlerimizden yargımıza, Polis Teşkilatımızdan istihbarat kuruluşlarımıza, okullarımızdan hastanelerimize kadar her yere sızabilen ihanet şebekelerine karşı kendimizi güçlendirmeliyiz. Bu ihanet şebekesinin adı PKK da olsa, FETÖ de olsa, DAEŞ de olsa, başka örgüt de olsa fark etmez. Örgütlerin isimleri değişebilir, kadroları değişebilir, söylemleri değişebilir; ama hepsinin de Türk milletinin, Türk Devletinin düşmanları olduğu gerçeği asla değişmez. Geldiğimiz noktada saflar gayet net; bir tarafta tüm kurumlarıla, tüm siyasi partileriyle, tüm kesimleriyle Türkiye Cumhuriyeti Devleti vardır, diğer tarafta ise kimi etnik istismar, kimi dini istismar, kimi ideolojik sapkınlık içinde olan terör örgütleri vardır, onların arkasındaki karanlık güçler vardır. Devletinden, milletinden, haktan ve hakikatten yana olan herkes bugün burada, Yenikapi'dadir. Buradan 80 vilayete selam olsun, buradan 79 milyona selam olsun. Terör örgütleri mensuplarının ise kimi adliyede akıbetini bekliyor, kimi cezaevinde cezasın çekiyor, kimi de mezarda nihai hesabını veriyor. Onların arkalarındaki güçleri de çok iyi biliyoruz, vakti, saati geldiğinde hesaplarını önlerine koyacağız. Yakaladığımız bu birlik ve beraberlik ruhunu en iyi şekilde değerlendirerek 15 Temmuz’u daha güçlü, daha büyük, daha müreffeh Türkiye'nin inşası için bir milat haline dönüștürmeliyiz. Yakın tarihimizin vicdanları kanatan, kafalarda soru işaretleri oluşturan tüm sorunlu, sıkıntıl olaylarım yeniden masaya yatırarak eksikleri, yanlşları ortaya koymalyyz. FETÖ ihanet çetesinin Türk Silahlı Kuvvetleri'ndeki etkinliğinin önünü açan davaları yeni baştan incelemeliyiz. Buna benzer birçok davaları incelemeliyiz. Şaibeli tüm sinavları, tüm işlemleri gözden geçirmeliyiz. Bu örgütün gayrimeşru şekilde elde ettiği güçle dizayn etmek istediği siyaseti, medyayı, iş dünyasını yeniden kendi tabii seyrine oturtmaliyız. Yurt içinde milletimizin dini hassasiyetini, merhametini, iyilik ve yardımlaşma duyguların istismar ederek elde ettikleri tüm imkânları milletimizin emrine vermeliyiz. Hiç kimse kapatılan yurtlardan, okullardan, evlerden dolayı endişeye kapılmasın, gerek devletimizin ilgili kurumları, gerekse ayn alanda hizmet veren sivil toplum kuruluşlarımız çok daha iyisiyle, çok daha fazlasıyla bu boşluğu dolduracaklardır. Yurt dişında ülkemizin adın ve itibarın da kullanarak elde ettikleri imkânları da asli sahibine, yani devletimize ve milletimize kazandırmalyız. Hükümetimiz olağanüstü hal ilan sonrasında sahip olduğu yetkiyle tüm bu alanlarda çok önemli adımlar attı, atmaya devam ediyor. Gazi Meclisimiz de bu konuda üzerine düşenleri yapıyor, yapmayı sürdürecektir. Siyasi partilerimizin ve medyamızın da bu süreci çok iyi değerlendirerek inanıyorum ki desteğini verecek ve bu yasalar, Anayasa değişikliği, yasa değişikliği veya yeni yasalar, bunlar hızla hazırlanacaktır.

Kardeşlerim; 3 haftadır her vesileyle ifade ettiğimiz bir hususu burada bilhassa tekrarlamak istiyorum: 15 Temmuz, evet, bir yönüyle ordumuz içine sizmış FETÖ ihanet şebekesi mensuplarının başlattığı bir darbe girişimidir. Ama hadise sadece bundan ibaret değildir, ayn zamanda PKK ve DAEŞ'in silahl eylemleriyle elde edilmek istenen neticenin, asker elbisesi giymiş teröristler eliyle yeni bir safhaya çıkartılma girişimidir. Yani bu girişim aynı zamanda bir terör eylemidir. Tüm bu özelliklerinin yanı sıra, 15 Temmuz ülkesine ve milletine ihanet eden bir silahl güç eliyle ülkemizi işgal girişimlidir. Şayet darbe başarılı olsaydı, bin ylldır bizim bu coğrafyanın kimlere altın tepsi içinde sunulacağını hepimiz gayet iyi biliyoruz. 15 Temmuz gecesi işte tüm bu gerçekleri AK Partilisiyle, CHP'liyse, MHP'lisiyle, diğer partilere mensup vatandaşlarımızla millet olarak hep birlikte gördük. 15 Temmuz gecesi bu gerçeği Türk'üyle, Kürt’üyle, Laz’yyla, 
Boşnak'ıyla, Çerkezìyle, Arap'ıyla, Roman'ıyla, 79 milyon hep birlikte gördüğ̈̈müz için sokaklarda oтиz omuza mücadele ettik. O gece insanlar partisini değil, hayat biçimini değil, meşrebini değil, kendi çıkarın değil, ülke ve millet olarak topyekûn istiklalimizi ve istikbalimizi düşünmek suretiyle mermilerin önünde kucak kucağa şehit oldu, gazi oldu. Minarelerimizden susturulmak istenen ezanlar yerine, tam aksine minarelerden ezan sesleri yükseldi, salalar yükseldi. Hiçbir çıkar insanın kendi canından daha önce değildir, daha tatl değildir. O gece darbecilerin karşısına dikilenler şayet ülkesi bağımsızlı̆̆ını kaybederse, milletinin geleceği kararırsa geride zaten hiçbir şey kalmayacağını çok iyi biliyordu. Ben bu muhteşem buluşmada buradan tüm şehitlerimize Allah'tan rahmet diliyorum. Tüm gazilerimize tekrar Rabbimden şifalar diliyorum. Bizim ylllardır dilimizden düşürmediğimiz 'milli irade' işte bu şehitlerimizle güç kazand, gazilerimizle güç kazandi. Bunun için milletimizin her bir ferdinin kendi özgür iradesiyle verdiği kararlara teslim olmak, boğun eğmek gerektiğini savunuyoruz. Milletimiz o muazzam irfaniyla daima en doğruyu, en hayırlyy, en faydalıy bulmuştur, bulacaktır. Bu millete, 79 milyon vatandaşımıza bakıp, 'eğitimsiz, pısırık, işe yaramaz bir insan yı̆̆ını' gördüklerini söyleyenler, zaman zaman söylüyorum, 15 Temmuz'da hayatlarının en büyük şokunu, en büyük mahcubiyetini yaşamışlardır. Artık şu gerçeği herkesin kabul etme zamanı gelmiştir: Bu milletin mayası sağlamdır. Aynı şekilde tabi ki Ömer Halis’i unutamayız. O ki Özel Kuvvetler'e saldırı düzenlendiği zaman o bir astsubay edasıla komutanının verdiği talimatı aninda yerine getirmek suretiyle onu anlindan vurarak öldürdü, kendisi de şahadete yürüdü. Silahl Kuvvetlerimizin, evet, aynı şekilde yüreğiyle, cesaretiyle kendini ortaya koyan tüm birimlerine, Genelkurmay Başkanımıza, kuvvet komutanlarımıza huzurlarınızda ayrıca teşekkür ediyorum. 15 Temmuz gecesi ülkemizle birlikte Almanya, Fransa, İngiltere, Belçika, Hollanda, Amerika, velhasıl nerede bir Türk varsa orada kalpleri bizim için atan kardeşlerimiz de vardı. Buradan yurt dişındaki vatandaşlarımıza da şükranlarımı sunuyorum. Bu vatandaşlarımızın Batı medyasının tarizleri, tacizleri, olumsuz yayınları sebebiyle zor günler geçirdiklerini biliyorum. İște Almanya; ben video konferansla orada mitinge bağlanacaktım, bağlatmadılar, olumsuz karar verdiler. Hani demokrasi? Ama Kandil'dekilere video konferansla yayn yaptırdılar. Ne olursa olsun yarılar onlar için bekledikleri gibi olmayacak, bumerang gibi onları vuracak. Beslesinler o teröristleri, yarm onlara çarpacaklar.

Cumhurbaşkanı Erdoğan'ın 15 Temmuz Darbe ve İşgal Girişiminden sonra Yenikapı'da yaptı̆̆ı konuşmanın analizinin, Dijk'in metoduyla yapılacağı daha önce belirtilmişti. Dijk (2002), bir grup tarafından paylaşılan sosyal temsillerin (bilgi, tutumlar) altta yatan ideolojilerle örgütlenebileceği üzerinden hareket etmektedir. Ona göre ideolojiler tanım gereği genel ve soyuttur, çünkü farklı sosyal alanlardaki birçok farklı tutum için geçerli olmalıdırlar. Soyutlamanın düzeyi ve sosyal bilişin karmaşı kontrolü, deneyimlerden (modeller) veya doğrudan endoktrinasyondan kapsamlı sosyal öğrenme gerektirir. Bu nedenle, ideolojiler gelişim aşamasında göreceli olarak geç elde edilir ve tüm grup üyeleri tarafından ayrıntılı bir şekilde öğrenilemez. Bazı grup uzmanları (ideologlar) "sıradan" grup üyelerinden daha kapsamlı ideolojilere sahip olacaklardır. Her ne kadar siyasi ideolojilerde klasik çalışma ve çağdaş sosyal psikolojideki bazı yönelimler, insanların istikrarlı ideolojilere sahip olduğunu inkâr etse de, insanların günlük yaşamları ideolojilerle örgütlenebilir. İdeolojilerin her şeyden önce üyelik kriterleri, faaliyetler, hedefler, değerler / normlar, sosyal konum ve kaynaklar gibi 
kategorilerle grup benlik şeması tarafından organize edildiği düşünülmektedir. Bunlar, kendi grubunu ve diğer gruplarla olan ilişkisini kendi kendine tanımlayan önemli bilgilerin temsil edildiği kategorilerdir: Biz kimiz, ne yapıyoruz, hangi amaçlarla vb? Bu çalışmada Erdoğan'ın milliyetçilik temelinde hareket ettiği görülmektedir. Fetullahçı terör örgütü başta olmak üzere, Türkiye'ye yönelik terörist saldırılar ve bunların arkasında küresel güç odaklarına karşı halkı uyarmak, milli birlik, bütünlük ve bağımsızlığı devam ettirmek, Erdoğan’ın söylemlerindeki milliyetçi nosyonları oluştururken, devlete ve millete karşı tehlike arz eden terörist yapılar öreki olarak konumlandırılmaktadır.

Dijk'in (2002) söylemin ideolojik boyutunu incelerken kullandığı metoda geri dönülecek olursa, politik söylemin tanımı için bağlamsallaştırmanın önemi göz önüne alındığında, bağlamın (bilişsel) analizine özel dikkat etmek gerekmektedir. Burada iki yapı bulunmaktadır: bağlam ve politik söylemin yapısı. Bağlam katılımcıların iletişimsel olayların zihinsel modelleri açısından tanımlanmalıdır. Yani, kendileri ve diğer katılımcıların ve diğer söylemle ilgili diğer iletişimsel durumlar kategorilerinin, örneğin; - genel alan (örneğin, politika) - genel toplumsal eylem (mevzuat) - mevcut ortam (zaman, konum) - mevcut koşullar - mevcut etkileşim (siyasi tartışma) - mevcut söylem türü (konuşma) - çeşitli türler katılımcıların rolü (konuşmacı, milletvekili, Partisi, ırkı, cinsiyeti, yaşı vb.), - katılımcıların bilişleri (hedefler, bilgi, inançlar vb). Ayrıca birçok politik söylem türünün metinsel terimlerden ziyade bağlamsal olarak tanımlandığı kabul edilmektedir. Siyasal söylem, öncelikle konu ya da üslupla değil, kiminle, ne zaman ve hangi amaçlarla konuştuğu ile tasvir edilir. Başka bir deyişle, siyasal söylem, siyasal süreç içindeki işlevleri nedeniyle özellikle "siyasal" dır. Bu minvalde Cumhurbaşkanı Erdoğan'ın konuşması uygun bir miting konuşmasıdır. Parlamentodaki gibi belirli bir süre ve kısitlamalardan ziyade uzun bir süreye sahiptir ve geniş bir kesime hitap edebilmektedir. Zaten konuşmasında Türkiye’nin bütün toplumsal kesimlerini bir araya getirdiğini vurgulamaktadır. Konuşmanın yapıldığı dönem ise darbe girişiminden kısa bir süre sonrası ve toplumsal hassasiyetin yüksek olduğu bir evre olması da önemlidir. 15 Temmuz Gecesi doğrudan hedefi ve devletin en üst temsilcisi yani Cumhurbaşkanı olması hasebiyle yaptığı konuşmanın bağlamı kendisi tarafından oluşturulmaktadır. Burada "biz" zamiri önem arz etmekte, 15 Temmuz gecesi tanklara, uçaklara ve silahlara karşı direnen Türk milleti, vatansever güvenlik güçleri ve devlet yöneticileriyle birlikte darbe karşısında duran herkes "biz"i oluşturmaktadır. "Devletten, milletten, haktan ve hakikatten yana olanlar burada" söylemi buna işaret etmektedir. Bunun karşısında ise öteki olarak başta terör örgütü Fetö olmak üzere bütün terör örgütleri, bunların arkasındaki karanlık güçler ve 16 Temmuz sabahı darbenin başarısız olmasına üzülenler bulunmaktadır. Cumhurbaşkanı Erdoğan'ın konuşmasının amacı ise Fetönün bir ihanet şebekesi olduğunu ortaya koymak, devleti Fetullahçı teröristlerden temizlemek, 15 Temmuz gecesi Türk milletinin destansı mücadelesini anlatmak ve devletin yıkılmayacağını göstermektir.

Dijk'e (2002) göre birçok söylem yapısı bağlam modellerinin bir işlevidir. Bununla birlikte, söylem sadece bağlam modelleri ile değil, aynı zamanda olay modelleri ile de sınırlandırılmıştır, yani konuşmacı olayların yanı sıra yukarıda da belirtildiği gibi grup üyeleri tarafından paylaşılan daha genel sosyal temsillerle yorumlanır. Politik söylemin tanımı için önemli olan 
önerildiği gibi, bu tür yapıların siyasi yapı ve süreçlerle ilgili olduğu söylenebilir. Cumhurbaşkanı Erdoğan'ın Yenikapı Mitinginde yaptığı konuşmadan da görüleceği üzere, darbe girişiminin başarısızlığa uğratılmasında Türk milletinin rolü ve devlete yönelik tehditler -başta Fetö olmak üzere- temelinde milliyetçi bir söylem geliştirdiği görülmektedir. Bu söylemin milliyetçiliğe içkin yapısını ortaya koyabilmek için, Dijk'in metodundaki politik söylemin yapılarını, konular, şema, anlambilim, stil ve retorik bağlamında incelemek gerekmektedir. Konu, siyasal ve diğer söylem biçimlerinde hangi bilgilerin önemli ya da güncel olduğu vurgulandığı alandır. Cumhurbaşkanı Erdoğan'ın konuşmasının temel konusu 15 Temmuz Darbe ve İşgal girişimi olmakla birlikte bunun altında değindiği birçok konu bulunmaktadır. Bunlar, (1) milletin esareti kabul etmemesi, (2) Fetö terör örgütü, (3) Devletin kılcal damarlarına kadar girmiş olan Fetullahçı teröristlerle mücadele, (4) 15 Temmuzun bir milat olarak kabul edilmesi ve daha güçlü, müreffeh bir devlet inşası, (5) 15 Temmuzla birlikte terör örgütlerinin saldırılarını yeni bir aşamaya getirmiş olmaları ve maşa olarak kullanılmalarıdır. Bütün bu konuların temelinde devletin varlığını devam ettirmesi, milli birlik, bütünlük ve bağımsızlığımızın korunması, Cumhurbaşkanı Erdoğan’ın söylemlerinde ön plana çıkmaktadır. Terör örgütleri içinde en sinsi ve tehlikeli yapının Fetö olduğu, bunlarla her alanda mücadele edildiği ve edileceği, gerekirse idam cezasının yeniden getirileceği -milletin de istemesi durumunda- vurgulanmaktadır.

Söylemin şematik yapısı, konuşmacının siyasi pozisyonu, konuşmada belirttiği konular bağlamında dinleyicileri ikna etmek için ön plana çıkardığı söylemler oluşturmaktadır. Anlambilim hususu ise, siyasi bağlam modellerinin, güncel olay modellerinde hangi bilgilerinin söylemle ilgili olarak dâhil edilip edilmeyeceğini bağlıdır. Bu, hem küresel anlamlar için, hem de asıl metin veya konuşma cümlelerinde ifade edilen yerel anlamlar için geçerlidir. Bu seçimi kontrol eden önemli bir bağlam kategorisi, konuşmacı ve alıcıların, yerel anlamların karmaşıklı̆̆ını da etkileyebilecek siyasi ideolojisidir (Dijk, 2002). Cumhurbaşkanı Erdoğan'ın yukarıdaki konuşmasında, milliyetçi ideolojiyi destekleyecek bir şekilde şematik bir yapı biçimlendirdiği görülmektedir: (a) 15 Temmuz bir işgal girişimidir, (b) Devlet bağımsızlığını kaybederse, milletin geleceği kararır, (c) Darbe girişimi başarılı olsaydı bin yıldır bizim olan bu vatanın kimlere altın tepsi içinde sunulacağını çok iyi biliyoruz, (d) Fetö ihanet şebekesinin devletten ve milletten aldıklarını sahiplerine geri vereceğiz. Bütün bunların yanında yerel anlambilim açısından konuşmada öne çıkan söylemler şunlardır: (a) O gece adeta ölümü öldürerek sokakları, meydanları dolduran milyonlarca vatandaşımız içinden şehitlik ve gazilik şerefine layık olanlar isimlerini tarihe altın harflerle yazdırdılar, (b) Bir olacağız, iri olacağız, diri olacağız, kardeş olacağız, hep birlikte Türkiye olacağız, (c) Bu milletin imanını, bu milletin inancını, bu milletin dirayetini o hiç hesaba katmadı, (d) Örgütlerin isimleri değişebilir, kadroları değişebilir, söylemleri değişebilir; ama hepsinin de Türk milletinin, Türk Devletinin düşmanları olduğu gerçeği asla değişmez. Böylece, milliyetçi öğeler, İslami bazı kavramlarla iman, şehitlik, gazilik- harmanlanarak, konuşmanın şematik yapısını ve dinleyicilerin anlam dünyasında yansımasının ifadesi olan yerel anlambilimini şekillendirmektedir.

Söylemin yapısal unsurlarının sonuncusu, politik söylemin stili ve retoriğidir. Semantik temsiller değişken yüzey yapılarında, yani belirli bir sözcükleşme, sözdizimsel yapılar ve ses, 
baskı veya görüntülerin belirli özellikleri ile ifade edilir, ayrıca altta yatan anlamların vurgulanmasina veya bu vurguyu üreten retorik cihazlarla belirtilir (Dijk, 2002). Cumhurbaşkanı Erdoğan'ın Yenikapı'da yaptı̆̆ı konuşmanın stil ve retorik açısından analizinde, tarihsel analojiler, şiirler, şarkı sözleri, kahramanlık temaları ve Türkiye'ye yönelik bu tarz saldırılara karşı meydan okuma söylemi belirgin bir şekilde görülmektedir. Tarihsel analojiler bağlamında, 15 Temmuz gecesi destanlaşan mücadele, 1071 Malazgirt Zaferi, Süleyman Şah, Osman Gazi, Çanakkale Zaferi, Milli Mücadele ve Mustafa Kemal Atatürk sembolleriyle özdeşleştirilmektedir. Buradaki ilk vurgu mekânsal niteliktedir. Çünkü Malazgirt zaferiyle Anadolu kapıları Türklere açılmış, Çanakkale zaferi ve Milli Mücadeleyle birlikte Türklerin Anadolu'dan hiçbir zaman çıkarılamayacağı kesinleşmişti. Dolayısıyla bu benzetmeler vasitasıyla Anadolu'nun ilelebet Türk yurdu olarak kalacağının üzerinde durulmaktadır. Nitekim "darbe başarılı olsaydı, bu vatanın altın tepsi içinde kimlere sunulacağını da çok iyi biliyoruz" söylemi de bunu desteklemekte; Fetullahçı teröristlerin amacının, Türk vatanını, arkalarındaki karanlık güçlere peşkeş çekeceğinin altı çizilmektedir. Cumhurbaşkanı Erdoğan'ın konuşmasında vatan vurgusu, devlet vurgusuyla birlikte işlenmektedir. Bu bağlamda Osman Gazi’nin beyliğini kurarken belirlediği ilkelere, Süleyman Şah'a ve Milli Mücadele sonucunda modern Türkiye Cumhuriyetini kuran Mustafa Kemal Atatürk'e atıf yapılmaktadır. Osmanlı ve Cumhuriyetin kurucu kodları ve bu dönemlerde verilen mücadeleyle 15 Temmuz gecesi devletin ve milletin darbeye karşı direnişi özdeşleştirilmektedir. Burada Cumhurbaşkanı Erdoğan'ın 15 Temmuzu bir milat olarak görmesinin de altı çizilmelidir. Türkiye'nin bu süreçten zayıflayarak değil, daha fazla güçlenerek çıacağını belirten Cumhurbaşkanı Erdoğan, Cumhuriyetin temel mottosu olan "muassır medeniyetler" seviyesinin de aşılması gereken bir hedef olarak zikretmektedir. Yine Cumhurbaşkanı Erdoğan'ın retoriğini biçimlendiren en önemli olgu, Türk milletinin ve milliyetçi devlet görevlilerinin -güvenlik güçleri- 15 Temmuz gecesi darbe karşısında gösterdikleri destansı mücadeledir. Bu bağlamda, darbeye direnirken vücudu parçalanan, kafası kopan şehitleri örnek olarak vermekte, tankların altına yatıp kolunu kaybeden gaziyle yaşadığı diyalogdan bahsetmektedir. Tankların altına yatan, mermilere, helikopterlerin ve savaş uçakların bombalarına göğüs geren Türk milleti, Cumhurbaşkanı için darbe gecesinin en büyük kahramanıdır. Doğal olarak darbe gecesinin önemli kahramanlarından biri olan şehit Ömer Halis Demir'den de söz etmektedir. İnsanların darbe karşısındaki direnişini ise devlet, millet, vatan ve bağımsızlık kavramları üzerinden tasvir eden Cumhurbaşkanı, Türk milletinin esareti kabul etmeyeceğini dile getirmektedir. Cumhurbaşkanı Erdoğan, milliyetçi retoriğini şekillendirirken sıklıkla şiir, İstiklal Marşı ve şarkı sözlerinden de yararlanmaktadır. Bu bağlamda milliyetçi-muhafazakâr kodlarla hareket etmekte; "İmandır o cevher ki ilahi ne büyüktür, imansız olan paslı yürek sinede yüktür", "Kim bu cennet vatanın uğruna olmaz ki feda...", "Siper et gövdeni dursun bu hayâsızca akın" ve milliyetçi sanatçı Esat Kabaklı'nın seslendirdiği "Gez oğlum, vatanına göz dikeni ez oğlum” şarkısının sözlerini kürsüde, darbeye direnen milleti tasvir ve motive etmek için okumaktadır. Son olarak, Türkiye'ye karşı gerçekleştirilen bu saldırının, hem bir işgal girişimi, hem de bir terörist eylem olduğunu ifade eden Cumhurbaşkanı Erdoğan, Fetullahçı teröristlere ayrı bir parantez açmaktadır. Bu terörist örgüte karşı kapsamlı bir mücadelenin verileceği, siyasal ve toplumsal yaşamın her alanında bu örgütün temizleneceği, gerekirse ve toplum talep ederse idam cezasının geri getirilebileceğini 
belirten Cumhurbaşkanı, aynı zamanda bunların, karanlık güçler tarafından kontrol edilen maşalar olduklarını da düşünmektedir. Yine de siyasal, sosyal ve ekonomik darbelerin yanında artık Türkiye'nin askeri darbelere karşı da güçlü olduğu söylemi, Cumhurbaşkanın en temel vurgusudur.

\section{Sonuç}

15 Temmuz Darbe ve İşgal girişimi, Cumhuriyet tarihinde Türkiye üzerinde oynanan oyunların fiili saldırıya dönüştüğü en mühim hadise olduğu söylenebilir. Darbe girişiminin yaşandığg gece, devletini ve milletini seven her Türk vatandaşı bu hain girişime direnerek başarıya ulaşmasını engelledi. Bu süreçle birlikte Türkiye'de milliyetçilik yeni bir ivme kazandı. Siyasal anlamda AK Parti ve MHP arasında başlayan yakın işbirliği bir ittifaka dönüştü ve bu ittifak Cumhur İttifakı- yapılan bütün seçimlerden zaferle ayrıldı. Toplumsal anlamda da milliyetçilik baskın bir ideoloji haline gelmiş; TV dizileri, filmleri, milliyetçi sembollerin dolaşıma sokulması, 15 Temmuzla ilgili yapılan anıtlar vb bu süreci desteklemiştir. 15 Temmuz Darbe ve İşgal girişiminden kırk gün sonra Türkiye, terörle mücadele, milli güvenlik ve çıkarlar temelinde sınırötesi askeri operasyonlara başlamış, Fırat Kalkanı, Zeytin Dalı ve Barış Pınarları operasyonlarıyla milliyetçilik siyasal ve toplumsal konsolidasyonunu sağlamıştır. Bu sürecin doğal bir ürünü olarak siyasi liderler ve karar vericilerin retoriklerini milliyetçilik şekillendirmiştir.

Cumhurbaşkanı Erdoğan'ın darbe girişiminden çok kısa bir süre sonra Yenikapı'da yaptı̆̆ konuşma, milliyetçi retoriğin en mümtaz örneğini teşkil etmektedir. Darbe girişiminde doğrudan hedef alınan, Türkiye Cumhuriyetinin lideri olan ve darbe gecesi halkı demokrasiyi ve devleti savunmak için sokaklara çağıran Cumhurbaşkanı Erdoğan, Yenikapı'da toplumun bütün kesimlerinden temsilcilerin bulunduğu bir ortamda bu konuşmasını gerçekleştirmiştir. Dolayısıyla, milli birlik ve bütünlük temsili olarak sağlanmış ve darbeden kısa bir süre sonra bu mitingin gerçekleştirilmesi suretiyle milliyetçilik her anlamda karşıllk bulmuştur. Tarihsel analojiler, kahramanlık anlatıları, Türkiye'ye yönelik saldırılar, milli birlik ve bütünlük, devlet, vatan, millet, bağımsızlık, ezan, şehitlik, gazilik ve iman gibi milliyetçi-muhafazakâr-İslami semboller, Cumhurbaşkanı Erdoğan'ın söylemlerinde yer almaktadır. Ancak bu söylem kümesindeki İslami-muhafazakâr söylemlerin milliyetçiliğin içeriğini doldurma işlevine sahip olduğu görülmektedir. Çünkü konuşmanın ideolojik alt yapısını milliyetçilik oluşturmaktadır. Özellikle Fetullahçı teröristlerin bir işgal girişiminde bulunduğunu belirtmesi, asıl amacın bağımsızlığımıza son verilerek devletin yok edilmesi ve bu ülkenin "altın tepside" başkalarına sunulacak olması, Cumhurbaşkanı Erdoğan'ın temel vurgularıdır. Terör örgütleri, başta Fetö olmak üzere "Türk milletinin ve Türk devletinin en büyük düşmanıdır" retoriği, bütün konuşmanın özeti hüviyetindedir. 15 Temmuz Darbe ve İşgal girişimi, Cumhurbaşkanı Erdoğan'ın Yenikapı konuşmasının analizi temelinde, Türk milliyetçiliğinin iki temel niteliğini ön plana çıarmıştır. Bunlardan birincisi, Türk milliyetçiliğinin reaksiyoner karakteridir. Darbeye karşı gerçekleştirilen direniş ve Cumhurbaşkanı Erdoğan'ın bunu konuşmasında sıklıkla kullanması, darbe ve işgal girişimi karşısında Türk milliyetçiliğinin tepkisel karakterinin görünür olmasına neden olmuştur. İkinci nitelik ise devlet olgusudur. Cumhurbaşkanı Erdoğan'ın 15 Temmuz'u" işgal girişimi” olarak tanımlaması, "bin yıllık vatan" vurgusu, 
Osmanlı ve Türkiye Cumhuriyetinin kurucu kodlarına yapılan atıfla devlette süreklilik temasını işlemesi ve bütün terör örgütlerini Türk devletinin düşmanı olarak ifade etmesi, Türk milliyetçiliğinin devlete dayalı bir ideoloji olması niteliğiyle uyumludur. Nitekim Cumhurbaşkanı Erdoğan için asıl mesele, bağımsızlık, vatan, ezan, şehitlik vs gibi kavramlarla içeriğini doldurduğu devlet olgusu ve onu koruma iç güdüsüdür.

\section{Kaynakça}

Aktürk, Ş. (2012). Regimes Of Ethnicity And Nationhood In Germany, Russia And Turkey. Cambridge: Cambridge.

Ayvazoğlu, B. (2009). Tanrıdağ’dan Hira Daği'na Uzun İnce Yollar, Tanıl Bora ve Murat Gültekingil (Ed), Modern Türkiye'de Siyasi Düşünce: Milliyetçilik Cilt 4 içinde (s. 541579), İstanbul: İletişim.

Belge, M. (Ocak 2003) Milliyetçilik ve Sol, Birikim. 165, http://www.birikimdergisi.com/sayi/165/milliyetcilik-ve-sol.

Bilig, M. (2002). Banal Milliyetçilik. Çev. Cem Şişkolar, İstanbul: Gelenek.

Bölükbaşı, Y. Z. (2018). Türkçü-Turancı Milliyetçiliğin Düşünsel Temelleri Üzerine Bir İnceleme. Akademik Hassasiyetler, 5(10), 45-60.

Bölükbaşı, Y. Z. (2019). Milliyetçilik ve Dış Politika: Türkiye’nin Kuzey Irak ve İsrail Politikalarına Teorik Bir Bakı̧. Ankara: Gazi Kitabevi.

Calhoun, C. (2012). Milliyetçilik. Çev. Bilgen Sütçüoğlu, İstanbul: İstanbul Bilgi Üniversitesi.

Çağaptay, S. (2009). Otuzlarda Türk Milliyetçiliği’nde Irk, Dil ve Etnisite, Tanıl Bora ve Murat Gültekingil (Ed), Modern Türkiye'de Siyasi Düşünce: Milliyetçilik Cilt 4 içinde (s. 245262), İstanbul: İletişim Yayınevi.

Çelik, H. ve Ekşi, H. (2008) Söylem Analizi. Marmara Üniversitesi Eğitim Bilimleri Fakültesi Dergisi. 27(1), 99-117.

Delannoi, G. (1998). Milliyetçilik ve İdeolojik Kataliz. Ed. Jean Leca (Ed), Uluslar ve Milliyetçilikler içinde (s. 32-45), Çev. Siren İdemen, İstanbul: Metis.

Dijk, T. A. V. (2008). Discourse and Context A Sociocognitive Approach. Cambridge: Cambridge University.

Dijk, T. A. V. (2002). Political Discourse and Political Cognition. Paul A. Chilton ve Chirstina Schaffner (Ed), Politics as Text and Talk Analytic Approaches to Political Discourse içinde (s. 203-239), Amsterdam ve Philadelphia: John Benjamins Publishing Company. 
Dönmez, R. Ö. (2015). Nationalism in Turkey Under Justice and Development Party Rule: The Logic of Masculunist Protection. Turkish Studies, 16(4), 1-15.

Fairclough, N. (2003). Analysing Discourse. London ve New York: Routledge.

Hobsbawm, E. J. (1993). Milletler ve Milliyetçilik. İstanbul: Ayrıntı.

Keitner, C. I. (2007). The Paradoxes of Nationalism: The French Revolution and Its Meaning for Contemporary Nation Building. New York: The State of New York University.

Kellas, J. G. (1998). The Politics of Nationalism and Ethnicity. London: Macmillan.

Kerestecioğlu, İ. Ö. (2016). Milliyetçilik: Uyuyan Güzeli Uyandıran Prensten Frankeştayn'ın Canavarına. Birsen Örs (Ed), 19. Yüzyıldan 20. Yüzyıla Modern Siyasal İdeolojiler içinde (s. 307-351), İstanbul: İstanbul Bilgi Üniversitesi.

Kohn, H. (1960). The Idea of Nationalism: A Study of its Origins and Backgraund, New York: Macmillan.

Maessen, E. (2014). Reassessing Turkish National Memory: An Analysis of Representation of Turkish National Memory by the AKP, Middle Eastern Studies, 50(2), 309-324.

Özkırımlı, U. (2009). Milliyetçilik Kuramları Eleştirel Bir Bakış. Ankara: Doğu Batı.

Potter, J. ve Wetherell, M. (2011). Discourse Analysis. Frederick J. Wertz vd (Ed), Five Ways of Doing Qualitative Analysis: Phenomenological Psychology, Grounded Theory, Discourse Analysis, Narrative Research, and Intuitive Inquiry içinde (s. 60-63), New York ve London: The Guilford.

Saraçoğlu, C. (Nisan 2013). AKP, Milliyetçilik ve Dış Politika: Bir Milliyetçilik Doktrini Olarak Stratejik Derinlik, Alternatif Politika, 5(1), 52-68.

Schulze, H. (2005). Avrupa'da Ulus ve Devlet. Çev. Timuçin Binder, İstanbul: Literatür.

Schöpflin, G. (2001). Nationalism: Evolution of Nationalism. Athanea S. Leoussi (Ed), Encyclopaedia of Nationalism içinde (s. 225-228), New Brunswick ve London: Transaction.

Smith, A. D. (2001). Nationalism. Athanea S. Leoussi (Ed), Encyclopaedia of Nationalism içinde (s. 222-225), New Brunswick ve London: Transaction.

Şahin, K. (Mayıs 2007). Bir İdeoloji Olarak Milliyetçilik. Akademik Bakış Dergisi, 12, 1-9.

Şener, N. (2018). Şeytanın Kara Kutusu. İstanbul: Destek.

White, J. (2013). Müslüman Milliyetçiliği ve Yeni Türkler. Çev. Fuat Güllüpınar ve Çoşkun Taştan, İstanbul: İletişim Yayınevi. 
Wodak, R. (2009). The Discourse of Politics in Action. London: Palgrave Macmillan.

Yalçıner, G. D. (2011). Eleştirel Söylem Analizi Çerçevesinde Avrupa Birliği’nde Kültürlerarası Diyalog. (Yayınlanmamış Doktora Tezi). Hacettepe Üniversitesi Sosyal Bilimler Enstitüsü, Ankara.

Yıldız, A. (2013). 'Ne Mutlu Türküm Diyebilene’ Türk Ulusal Kimliğinin Etno-Seküler Sinırları (1919-1938). İstanbul: İletişim.

Yücel, G. ve Bölükbaşı, Y. Z. (Ekim 2019). Türk Milliyetçiliğinde Yol Ayrımı: 1944 IrkçılıkTurancılık Davası. Milliyetçilik Araştırmaları Dergisi, 1(2), 5-34.

T. C. Cumhurbaşkanlığı. (07.08.2016). Demokrasi ve Şehitler Mitinginde Yaptıkları Konuşma. https://www.tccb.gov.tr/konusmalar/353/49925/demokrasi-ve-sehitler-mitingindeyaptiklari-konusma.html.

T. C. Cumhurbaşkanlığı. (2016). 10 Soruda 15 Temmuz Darbe Girişimi ve Fetullahçı Terör Örgütü. https://www.tccb.gov.tr/assets/dosya/15Temmuz/onsorudafeto_tr_en.pdf.

T. C. Cumhurbaşkanlığı. (2018). 15 Temmuz Darbe Girişimi ve Milletin Zaferi. https://www.tccb.gov.tr/assets/dosya/15Temmuz/15temmuz_tr.pdf.

Ahmet Zeki Üçok’tan FETÖ Uyarısı: Üst düzey bürokrasideki FETÖ'cüler hala görevde (22.05.2018). Aydınlık. https://www.aydinlik.com.tr/ahmet-zeki-ucok-tan-feto-uyarisiust-duzey-burokrasideki-feto-culer-gorevde-turkiye-mayis-2018.

Milliyetçi Hareket Partisi, https://www.mhp.org.tr/htmldocs/basbug/ozlu/mhp/ basbugumuzun_ozlu_sozleri.html. 